\title{
Credit Distortion, Firm Nature and Investment Efficiency
}

\author{
Lv Chen \\ Jinan University, Guangzhou, China \\ Email: 13007236362@163.com
}

How to cite this paper: Chen, L. (2018) Credit Distortion, Firm Nature and Investment Efficiency. American Journal of Industrial and Business Management, 8, 867-880.

https://doi.org/10.4236/ajibm.2018.84060

Received: March 26, 2018

Accepted: April 23, 2018

Published: April 26, 2018

Copyright $\odot 2018$ by author and Scientific Research Publishing Inc. This work is licensed under the Creative Commons Attribution International License (CC BY 4.0).

http://creativecommons.org/licenses/by/4.0/

(c) (i) Open Access

\begin{abstract}
Credit is the foremost external source of funds for enterprises. The allocation rationality of credit fund directly affects corporate financing constraints and further manipulates business investment actions. Based on government intervention, the credit market in China presents certain degree of allocation distortion, which means that state-owned companies have quantity and cost advantages over non state-owned companies in respect of the acquisition of credit resources. Taking listed A share in 2008-2015 as the samples, the thesis firstly introduces the interprovincial variables of credit allocation distortion to quantify external credit allocation distortion degree faced by companies and study investment inefficiency problems in state-owned companies and non state-owned companies. As proved by the empirical results: 1) comparing with state-owned companies, non state-owned companies encounter more grievous problems in underinvestment and overinvestment; 2) the aggravation of regional credit allocation distortion degree will significantly intensify overinvestment of state-owned companies and underinvestment of non state-owned companies in local regions. It fully indicates that the imbalance of credit resource allocation will encumber corporate investment efficiency.
\end{abstract}

\section{Keywords}

Credit Distortion, Firm Nature, Investment Efficiency,

Overinvestment/Underinvestment

\section{Introduction}

Limited by the undeveloped financial system in China, corporate financing channel primarily relies on the banking system. According to relevant statistics, until late November in 2017, domestic direct financing balance in non-financial companies simply accounted for approximately $15 \%$ of social financing scale. 
Obviously, bank credit size and allocation efficiency produce explicit and major influences on economic growth. While on the other hand, China now is still in the market-oriented transformation stage in which the "visible hand" of government plays a vital role in economic activities as usual. This could be reflected by government intervention in the banking system such as control of interest rate and also the control of state-owned companies. It leads to institutional constraints and market endogenous dual credit rationing problems in Chinese credit market, usually proved by the credit discrimination between state-owned and non state-owned companies. In other words, state-owned companies could earn more credit resources at a relatively lower cost but non state-owned companies confront more financing constraints.

In present stage, de-capacity, de-stocking and cost reduction remain to be the focus of reformation in China. While the main body of excess production capacity is exactly state-owned company. That is to say, regardless of the access to substantial financial resources, state-owned companies still have low capital utilization efficiency and behave overinvestment inefficiency actions. The implication of "cost reduction" could be primarily seen from the reduction of corporate financing costs in favor of the development of substantial economy. Comparing with state-owned companies, private companies face more financing difficulties.

Under the major context as stated above, it is of great importance to discuss about the different influences of interprovincial credit resource allocation distortion conditions on corporate investment efficiency in state-owned companies and non state-owned companies. For either state-owned companies or non state-owned companies, both underinvestment caused by abandoning good investment projects subject to financing constraints and overinvestment caused by misuse of free cash flow are expressions of investment inefficiency. While such investment inefficiency will in turn impair corporate values and reflect the loss of credit resource allocation efficiency.

In comparison with previous literature documents, this thesis firstly introduces the interprovincial variables of credit allocation distortion to quantify external credit allocation distortion degree faced by companies and study investment inefficiency problems of different companies. It is the innovation of research perspective. To be specific, it starts from a rare medium level to expound corporate investment efficiency; starts from a rare microscopic level to observe credit allocation distortion economic effects and deepen insights into the economic depression mechanism triggered by credit allocation distortion; and examines the intermediary role of corporate property.

Through the study, it can explain the reality of the corporate investment inefficiency on the one hand. On the other hand, it enriches the literature of credit rationing research field by deepening the mechanism that the credit allocation distorts the economic drag. Finally, it can provide theoretical support for continuous deepening of market reformation and reformation of state-owned companies. 
The arrangement of remaining parts is as follows. The second part is about theoretical analysis and research hypotheses; the third part is about research design; the fourth part is about empirical results and the last part is about conclusion.

\section{Theoretical Analysis and Research Hypotheses}

Under the hypothesis of perfect market, corporate investment decision is unrelated to corporate financing decision. Corporate external fund is the perfect replacement of internal fund which allows business investment to maximize corporate values and reach the optimal level. In reality, on the one hand, since fund providers fail to effectively discern the quality of fund borrowers due to the information asymmetry, they usually offer fund at a relatively higher cost. In general cases, high quality companies would have higher fund costs above perfect market costs. Expensive external financing costs prevent companies from obtaining the fund support required by optimal investment, and they have to heavily rely on internal financing which later triggers underinvestment [1]. In addition, such companies in the face of intense financing constraints show high investment-cash flow sensitivity [2]. This part of theory is often referred to as overinvestment theory under information asymmetry.

On the other hand, the separation of ownership and management right in modern companies results in the agency conflicts between shareholders and managers. Out of the pursuits for private profits, managers often have exclusive investment for "empire construction" [3] and make dedicated investment for "extortion" [4]. Projects with negative investment net present value accordingly bring about the loss of investment efficiency. Based on the agency theory, Jensen [5] put forward the "free capital flow hypothesis", and prove the high sensitivity between investment and free capital flow. In pursuit of personal control benefits, managers are usually reluctant to deliver part of capital flow to shareholders but turn to make expansion corporate investment and possibly give rise to overcapitalization.

As the foremost source of corporate external capital, credit market fund allocation mechanism directly restrains the availability of corporate credit fund and the cost of credit fund, therefore affecting corporate investment efficiency. During market-oriented reformation process, the financial system still suffers from government intervention in some degree so that institutional constraints and market endogenous dual credit rationing problems coexist in Chinese credit market. It implies that some companies in the market could not succeed in loan borrowing even with higher interest rate. Based on soft budget constraints in state-owned companies and the high-risk properties in small and medium-sized private companies under government intervention, ownership discrimination (where state-owned companies enjoy quantity and cost advantages over non state-owned companies in the acquisition of credit resources), or say, credit allocation distortion, becomes an important feature of credit rationing [6]. 
As for the difference between state-owned companies and non state-owned companies in investment efficiency, Xin et al. [7] conducted the research from the perspective of entrustment agency aroused by corporate property, finding that regional listed companies encountered overinvestment problems triggered by inefficient remuneration contract. Zhang and Wang [8] held that overinvestment of state-owned companies was caused by local government decision which internalized employment and taxation into the operation investment of state-owned companies. Jiang et al. [9] deemed that comparing with private companies, state-owned companies possessed absolute credit advantages but encountered more serious entrustment agency problems. This was also the reason why state-owned companies had apparently lower investment efficiency than private companies. Zhang [10] studied the influences of credit discrimination on the investment efficiency in state-owned companies and non state-owned companies under government-business relationship, finding that credit discrimination forced private companies to suffer from more financing constraints and overinvestment constraints than state-owned companies. Whereas, the study failed to elaborate different influences left on inefficient investment in state-owned companies and non state-owned companies by quantifying external credit resource allocation distortion degree faced by companies.

Based on above theoretical analysis, it can be considered that for principal-agent factors be controlled, higher credit allocation distortion means higher possibility for state-owned companies to acquire credit resources and higher free cash flow affluence degree which means higher overinvestment degree. In non state-owned companies, more intense credit financing constraints means more scarce internal cash flow and naturally, more serious overinvestment degree.

H1a: Higher credit distortion degree will lead to higher overinvestment degree in state-owned companies than non state-owned companies.

H1b: Credit allocation distortion aggravates overinvestment in state-owned companies by increasing free cash flow.

H2a: Higher credit distortion degree will lead to more serious underinvestment degree in non state-owned companies.

$\mathrm{H} 2 \mathrm{~b}$ : Credit allocation distortion aggravates underinvestment degree in non state-owned companies by increasing internal cash flow gap.

\section{Research Design}

\subsection{Sample Selection and Data Source}

Due to the implementation of the new accounting Standards in 2006, in order to keep the data consistent, this paper takes the data of all the listed shares of China's provinces for 2007-2015 years as a sample to study the different influence of credit distortion in the provinces on the investment efficiency of the listed state-owned and non state-owned companies. The total sample period for this article is 2008-2015 years, due to the estimated inefficiency of investment that requires lagging data. 
And then this thesis removes. 1) samples from all ${ }^{*} \mathrm{ST}$ and ST companies; 2) samples from financial industry; 3) samples from companies with less than one-year IPO period; 4) samples from companies with missing data. Finally, for eradicating the influences of extreme values, the thesis conducts winsorize processing on all extreme values below $1 \%$ and above $99 \%$ among all variables.

Data of the thesis come from CSMAR database, Wind database, and listed companies' reports, the data missing parts are manually searched from listed companies' reports.

\subsection{Variable Definition}

\subsubsection{Dependent Variable}

This thesis takes investment efficiency as the explained variable. At present, residual measurement model of Richardson [11] [12] is commonly adopted to estimate investment efficiency [13]. By constructing the optimal investment model of the enterprise, the model is used to indicate the degree of the inefficient investment; the model residual term $\varepsilon$ represents corporate inefficiency investment degree. Residual term $\varepsilon$ above 0 represents overinvestment and residual term $\varepsilon$ below 0 means underinvestment.

$$
\begin{aligned}
& \operatorname{Inv}_{i, t}= \alpha+\beta_{1} \text { Growth }_{i, t-1}+\beta_{2} \operatorname{Lev}_{i, t-1}+\beta_{3} \operatorname{Cash}_{i, t-1}+\beta_{4} \text { Age }_{i, t-1}+\beta_{5} \operatorname{Size}_{i, t-1} \\
&+\beta_{6} \operatorname{Ret}_{i, t-1}+\beta_{7} \operatorname{Inv}_{i, t-1}+\sum \text { year }+\sum \text { Industry }+\varepsilon_{i, t} \\
& \text { Over }-\operatorname{inv}_{i, t}=\operatorname{Inv}_{i, t}-\operatorname{Exp}_{\operatorname{Inv} v_{i, t}} \quad\left(\text { when } \operatorname{Inv}_{i, t}-\operatorname{Exp}_{I n v_{i, t}}>0\right) \\
& \text { Under }-i n v_{i, t}=-\left(\operatorname{Inv}_{i, t}-\operatorname{Exp}_{I n v_{i, t}}\right) \quad\left(\text { when } \operatorname{Inv}_{i, t}-\operatorname{Exp}_{I n v_{i, t}}<0\right)
\end{aligned}
$$

where in $I n v_{i, t}$ means the newly increased corporate capital investment in year $\mathrm{t}$ which standardizes total assets in early year $\mathrm{t}$; Growth $_{i, t-1}$ means corporate growth chance which is expressed by Tobin's q value in the end of last year; $\operatorname{Lev}_{i, t-1}$ means corporate asset-liability ratio in the end of year $t-1 ; \operatorname{Cash}_{i, t-1}$ means cash flow level which is calculated through dividing monetary capital in the end of year $\mathrm{t}-1$ by year-end total assets; $\mathrm{Age}_{i, t-1}$ means the IPO period until the end of year $\mathrm{t}-1$ which is calculated by its natural logarithm; Size $e_{i, t-1}$ means corporate size which is equal to total assets' natural logarithm in the end of year $t-1$; $\operatorname{Re} t_{i, t-1}$ means corporate share annual rate of return; simultaneously it controls industrial effects and annual effects.

\subsubsection{Independent Variable and Control Variables}

The thesis constructs the explaining variable-credit allocation distortion by reference to Liu and Zou. It defines distort $1=\lambda / \alpha$, wherein $\lambda$ means the proportion of state-owned listed company credit fund size in total listed company fund size, and $\alpha$ means the proportion of state-owned listed company gross output in total listed company gross output (output could be replaced by prime business revenues). It defines distort $2=\lambda / \delta$, wherein $\delta$ means the proportion of state-owned company employees in total listed companies. Distort 1 and distort 2 have experienced standardization processing. The thesis defines another unstandardized indicator distort $3=\lambda / \theta$, wherein $\theta$ means the pro- 
portion of non state-owned listed company credit fund size in total Listed company fund capital size. It defines distort 4 as the proportion of state-owned company bank credit resource in all provincial listed companies. Other explaining variables include $S O E, F C F$ and $S C F$.

In addition, the thesis chooses equity concentration degree (Top 1), equity balance degree (Top9_10), executive compensation (Tpay), cash flow level (Cash), business revenue increase rate (Growth), annual return on stock (Ret), $R O A$, industry and year as the control variables. The definition of all variables is shown as the following Table 1.

\subsection{Model Design}

Based on previous hypotheses and selection of variables, this thesis divides samples into the group of overinvestment \& free cash flow affluence and the group of underinvestment \& internal cash flow gap to construct the model. Meanwhile, for explaining the functional mechanism of credit distortion on corporate investment inefficiency, this thesis introduces the interaction item of credit distortion and corporate property, and the interaction item of credit distortion, corporate property and free cash flow/internal cash flow gap for verification. Specific model design flow is shown as follows.

$$
\begin{aligned}
& \text { Over }- \text { inv }_{i, t}=\alpha+\beta_{1} \text { distort }_{i, t}+\beta_{2} S O E+\beta_{3} f c f_{i, t}+\beta_{4} \text { distort }_{i, t} S O E \\
& +\beta_{5} \text { distort }_{i, t} \text { SOEfcf }_{i, t}+\beta_{6} \text { cash }_{i, t-1}+\beta_{7} \text { ROA }_{i, t-1}+\beta_{8} \text { growth }_{i, t-1} \\
& +\beta_{9} \text { ret }_{i, t-1}+\beta_{10} \text { top } 1_{i, t-1}+\beta_{11} \text { top9_1 } 1_{i, t-1}+\beta_{12} \text { tpay }_{i, t-1}+\sum \text { year } \\
& +\sum \text { Industry }+\varepsilon_{i, t}
\end{aligned}
$$

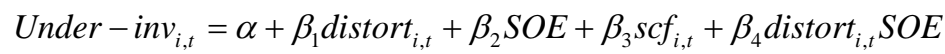

$$
\begin{aligned}
& +\beta_{5} \text { distort }_{i, t} \text { SOEscf }_{i, t}+\beta_{6} \text { cash }_{i, t-1}+\beta_{7} \text { ROA }_{i, t-1}+\beta_{8} \text { growth }_{i, t-1} \\
& +\beta_{9} \text { ret }_{i, t-1}+\beta_{10} \text { top } 1_{i, t-1}+\beta_{11} \text { top9_1 } 1_{i, t-1}+\beta_{12} \text { tpay }_{i, t-1}+\sum \text { year } \\
& +\sum \text { Industry }+\varepsilon_{i, t}
\end{aligned}
$$

\section{Empirical Results}

\subsection{Descriptive Statistics}

Table 2 reports the results of descriptive statistics of the main related variables in this paper. The total observed value of the variable investment efficiency is 13,942 , the mean value is 0 , and the distribution is good. The observed value of the variable overinvestment is 5244 , the ratio is $37.61 \%$, the mean is 0.059 , the maximum is 0.449 , and the observed value of the variable underinvestment is 8698 , the ratio is $62.39 \%$, the mean value is 0.036 , the maximum value is 0.314 . It can be seen that more listed companies face the underinvestment situation, but the excessive degree of overinvestment is more serious.

In addition, the degree of credit distortion is matched to the provincial listed companies. The total observed value of Distort 1, Distort 2, Distort 3 and Distort 4 is, respectively, $13,940,13,940,13,905,13,931$. The average value is 0.922 , $1.093,2.803,0.532$, which show that the state-owned companies possess more 
Table 1. Variable definition table.

\begin{tabular}{|c|c|c|c|}
\hline Variable type & Variable symbol & Variable name & Variable definition and description \\
\hline \multirow{5}{*}{$\begin{array}{l}\text { Dependent } \\
\text { variable }\end{array}$} & Over-inv & overinvestment & Equation (2) \\
\hline & Under-inv & underinvestment & Equation (3) \\
\hline & Distort 1 & credit distort 1 & $\begin{array}{l}\lambda / \alpha, \lambda \text { means the proportion of } \\
\text { state-owned listed company credit fund } \\
\text { size in total Listed company fund capital } \\
\text { size, and } \alpha \text { means the proportion of } \\
\text { state-owned listed company gross output } \\
\text { in total listed company gross output } \\
\text { (output could be replaced by prime } \\
\text { business revenues). }\end{array}$ \\
\hline & Distort 2 & credit distort 2 & $\begin{array}{l}\lambda / \delta, \delta \text { means the proportion of } \\
\text { state-owned company employees in total } \\
\text { listed A share companies. }\end{array}$ \\
\hline & Distort 3 & credit distort 3 & $\begin{array}{l}\lambda / \theta, \theta \text { means the proportion of listed } A \\
\text { share non state-owned company credit } \\
\text { fund size in total Listed company fund } \\
\text { capital size. }\end{array}$ \\
\hline \multirow{6}{*}{$\begin{array}{l}\text { Independent } \\
\text { variable }\end{array}$} & & & $\lambda$ means the proportion of state-owned \\
\hline & Distort 4 & credit distort 4 & $\begin{array}{l}\text { listed company credit fund size in total } \\
\text { Listed company fund capital size. }\end{array}$ \\
\hline & $S O E$ & Corporate property & $\begin{array}{l}1 \text { means state-owned company and } 0 \\
\text { means non state-owned company }\end{array}$ \\
\hline & $F C F$ & Free cash flow & $\begin{array}{l}\text { Free cash flow }=\text { (cash flow net amount } \\
\text { caused by corporate business operation } \\
\text { activities-due depreciation and } \\
\text { amortization)/total assets in the } \\
\text { beginning of the year-model (1)'s } \\
\text { predicted expected newly increased } \\
\text { investment. When the indicator is } \\
\text { positive. }\end{array}$ \\
\hline & $S C F$ & $\begin{array}{l}\text { Internal cash flow } \\
\text { gap }\end{array}$ & $\begin{array}{l}\text { Internal cash flow gap }=\text { (cash flow net } \\
\text { amount caused by corporate business } \\
\text { operation activities - due depreciation } \\
\text { and amortization)/total assets in the } \\
\text { beginning of the year-model (1)'s } \\
\text { predicted expected newly increased } \\
\text { investment. When the indicator is } \\
\text { negative, the absolute value should } \\
\text { bechosen. }\end{array}$ \\
\hline & Top 1 & $\begin{array}{c}\text { Equity } \\
\text { concentration } \\
\text { degree }\end{array}$ & $\begin{array}{l}\text { shareholding ratio of the 1st majority } \\
\text { shareholder }\end{array}$ \\
\hline \multirow[t]{2}{*}{$\begin{array}{c}\text { Control } \\
\text { variables }\end{array}$} & Top9_1 & $\begin{array}{l}\text { Equity balance } \\
\text { degree }\end{array}$ & $\begin{array}{l}\text { shareholding ratio of the } 2 \text { nd-10th } \\
\text { majority shareholder/shareholding ratio } \\
\text { of the } 1 \text { st majority shareholder }\end{array}$ \\
\hline & Tpay & $\begin{array}{c}\text { Executive } \\
\text { compensation }\end{array}$ & $\begin{array}{l}\text { natural logarithm of top three total } \\
\text { executive compensation }\end{array}$ \\
\hline
\end{tabular}




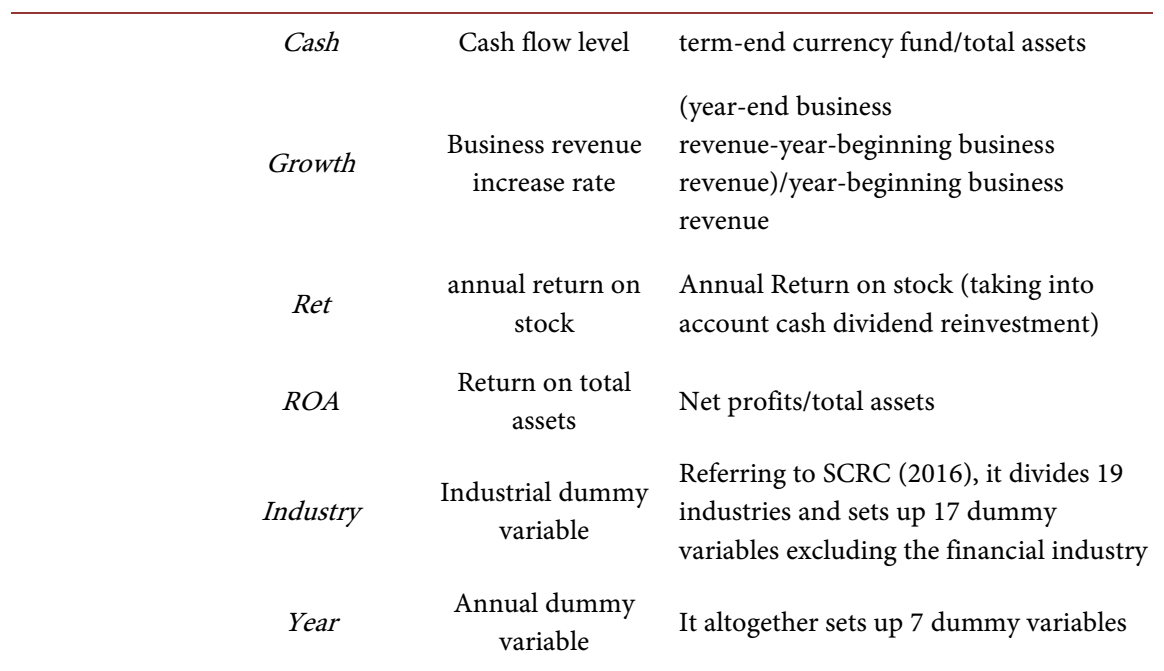

Table 2. Descriptive statistics.

\begin{tabular}{|c|c|c|c|c|c|}
\hline Variable & $\mathrm{N}$ & Mean & Std. Dev & Min & Max \\
\hline inv_eff & 13,942 & 0.000 & 0.070 & -0.314 & 0.449 \\
\hline over_inv & 5244 & 0.059 & 0.076 & 0.000 & 0.449 \\
\hline under_inv & 8698 & 0.036 & 0.033 & 0.000 & 0.314 \\
\hline distort 1 & 13,940 & 0.922 & 0.405 & 0.060 & 2.223 \\
\hline distort 2 & 13,940 & 1.093 & 0.521 & 0.057 & 2.888 \\
\hline distort 3 & 13,905 & 2.803 & 6.164 & 0.045 & 47.510 \\
\hline distort 4 & 13,931 & 0.532 & 0.229 & 0.043 & 0.979 \\
\hline$S O E$ & 13,942 & 0.458 & 0.498 & 0.000 & 1.000 \\
\hline$F C F$ & 5720 & 0.065 & 0.066 & 0.000 & 0.373 \\
\hline$S C F$ & 8222 & 0.073 & 0.068 & 0.000 & 0.502 \\
\hline cash & 13,941 & 0.175 & 0.126 & 0.008 & 0.671 \\
\hline$R O A$ & 13,942 & 0.060 & 0.067 & -0.184 & 0.297 \\
\hline growth & 13,942 & 0.131 & 0.336 & -0.620 & 1.778 \\
\hline Ret & 13,938 & 0.309 & 0.723 & -0.737 & 3.756 \\
\hline top 1 & 13,942 & 0.356 & 0.153 & 0.088 & 0.753 \\
\hline top9_1 & 13,942 & 0.754 & 0.698 & 0.033 & 3.552 \\
\hline tpay & 13,942 & 14.018 & 0.899 & 0.000 & 15.921 \\
\hline ind & 13,942 & 4.875 & 3.318 & 1.000 & 17.000 \\
\hline region & 13,942 & 14.673 & 9.855 & 1.000 & 31.000 \\
\hline
\end{tabular}

credit resources relative to non-state enterprises on the whole.

The average value of enterprise variables is 0.458 , it can be seen that $45.8 \%$ of the enterprises are state-owned enterprises. Another important explanation variable free cash flow, its sample observation value is 5720 , the maximum value is 
0.373; The internal cash flow Gap sample is 8222 , the average gap is 0.073 , and the maximum value is 0.502 .

\subsection{Correlation Analysis}

This thesis respectively conducts important variable correlation analysis on overinvestment \& free cash flow affluence group and underinvestment \& internal cash flow gap group. Table 3 and Table 4 explicitly show that interprovincial credit distortion's four measurement indicators do not have any significant correlation with corporate overinvestment and underinvestment. While there exists a significant correlation among the four indicators of credit distortion. The correlation coefficient of distort $1 \&$ distort 2 and distort $3 \&$ distort 4 is respectively 0.8347 and 0.5619 . The two group indicators have favorable substitutability. The correlation coefficient among other variables is relatively small. Therefore, the preliminary judgment is that there does not have severe muticollinearity problems among all variables.

\subsection{Results Analysis}

Table 5 reports the return of the investment efficiency model, the correlation coefficient is significant at $1 \%$, and the symbol of the variable coefficient coincides

Table 3. Variable correlation analysis on overinvestment \& free cash flow affluence group.

\begin{tabular}{cccccccc}
\hline & Over-inv & Distort 1 & Distort 2 & Distort 3 & Distort 4 & FCF & SOE \\
\hline Over-inV & 1 & & & & & & \\
Distort 1 & 0.0022 & 1 & & & & & \\
Distort 2 & -0.0089 & $0.8347^{* * *}$ & 1 & & & & \\
Distort 3 & 0.0112 & $0.2025^{* * *}$ & $0.0831^{* * *}$ & 1 & & & \\
Distort 4 & 0.0181 & $0.4316^{* * *}$ & $0.2123^{* * *}$ & $0.5619^{* * *}$ & 1 & & \\
FCF & $0.2135^{* * *}$ & $0.0363^{*}$ & 0.0251 & $0.0507^{* *}$ & $0.0798^{* * *}$ & 1 & \\
SOE & $-0.073^{* * *}$ & $-0.100^{* * *}$ & $-0.159^{* * *}$ & $0.1226^{* * *}$ & $0.2106^{* * *}$ & 0.0111 & 1 \\
\hline
\end{tabular}

Note: ${ }^{* * *},{ }^{* *}$, and ${ }^{*}$ represent the significance levels of $1 \%, 5 \%$, and $10 \%$, respectively.

Table 4. Variable correlation analysis on overinvestment \& free cash flow affluence group.

\begin{tabular}{cccccccc}
\hline & Under-inV & Distort 1 & Distort 2 & Distort 3 & Distort 4 & FCF & SOE \\
\hline Under_inV & 1 & & & & & & \\
Distort 1 & 0.0046 & 1 & & & & & \\
Distort 2 & 0.0143 & $0.8531^{* * *}$ & 1 & & & & \\
Distort 3 & 0.0248 & $0.2056^{* * *}$ & $0.1061^{* * *}$ & 1 & & & \\
Distort 4 & 0.001 & $0.4262^{* * *}$ & $0.2437^{* * *}$ & $0.5640^{* * *}$ & 1 & & \\
SOE & $-0.1^{* * *}$ & $-0.06^{* * *}$ & $-0.125^{* * *}$ & $0.1177^{* * *}$ & $0.1981^{* * *}$ & 1 & \\
$S C F$ & $0.2405^{* * *}$ & -0.011 & 0.0014 & 0.0053 & -0.004 & $-0.092^{* * *}$ & 1 \\
\hline
\end{tabular}

Note: ${ }^{* * *},{ }^{* *}$, and ${ }^{*}$ represent the significance levels of $1 \%, 5 \%$, and $10 \%$, respectively. 
Table 5. Regression results of investment efficiency.

\begin{tabular}{ccccccccc}
\hline & Cons. & $\mathrm{Q}$ & lev & cash & age & size & ret & inv \\
\hline coefficient & $-0.059^{* * *}$ & $0.003^{* * *}$ & $-0.008^{* * *}$ & $0.014^{* * *}$ & $-0.007^{* * *}$ & $0.002^{* * *}$ & $0.004^{* * *}$ & $0.482^{* * *}$ \\
$\mathrm{t}$ & -4.200 & 10.130 & -5.590 & 8.170 & -9.900 & 5.510 & 5.100 & 52.790 \\
Adj R^2 & 0.247 & $\mathrm{~F}$ & 153.580 & $\mathrm{~N}$ & 13942 & $\begin{array}{c}\text { Industry, } \\
\text { year }\end{array}$ & control & \\
\hline
\end{tabular}

with the Richardson (2006) model, which indicates that the model is effective. The regression value of the model can be used as the basis of the subsequent regression model. According to the results of the table, we can calculate the expected capital investment of the enterprise each year, and then calculate the corresponding free cash flow level of the enterprise.

Table 6 reports the regression results of overinvestment \& free cash flow affluence group. Credit distortion adopts the four indicators of distort 1, distort 2, distort 3 and distort4. FCF shows highly positive correlation with overinvestment in four models and supports the theoretical foundation of the thesis. Credit distortion does not have any significant direct influences on corporate overinvestment behaviors. In Model (1), (2) and (3), corporate property has a significant positive correlation with overinvestment, which means that non state-owned companies have more serious overinvestment degree than state-owned companies in case of free cash flow affluence. Positive distort $1 S O E$ and distort $2 S O E$ coefficients support thesis hypothesis H1a. It shows that if the region has higher regional credit distortion degree, state-owned companies would acquire more credit resources and aggravate overinvestment degree. While since the interaction coefficient of distort $S O E \& F C F$ is less significant, $\mathrm{H} 1 \mathrm{~b}$ is not testified.

Table 7 reports the regression results of underinvestment $\&$ internal cash flow gap group. The positive correlation between $S C F$ and underinvestment also supports the theoretical foundation of the thesis. Although there exists a significant positive correlation between credit distortion and corporate underinvestment in Model (3) and (4), it has rather weak direct influences because the correlation coefficient is simply 0.0003 and 0.005 . Corporate property shows significant negative correlation with corporate underinvestment in Model (1), (2) and (3), which proves that in case of internal cash flow shortage, non state-owned companies have more serious underinvestment degree than state-owned companies. The significant negative coefficient of distort3 SOE and distort4 SOE supports H2a. It means that if certain region has higher credit distortion degree, non state-owned companies would acquire less credit resources but face more financing constraints and more serious underinvestment degree. While because the coefficient of distort $S O E \& F C F$ is inconsistent with overinvestment group, $\mathrm{H} 2 \mathrm{~b}$ is not verified.

Besides, executive remuneration incentive has significant inhabiting effects on corporate overinvestment and underinvestment, which means that remuneration 
Table 6. Regression results of overinvestment \& free cash flow affluence group.

\begin{tabular}{|c|c|c|c|c|}
\hline \multirow{3}{*}{ Variable } & \multicolumn{4}{|c|}{ Over-inv } \\
\hline & Model (1) & Model (2) & Model (3) & Model (4) \\
\hline & coefficient & coefficient & coefficient & coefficient \\
\hline Distort 1 & -0.006 & & & \\
\hline Distort 2 & & $-0.008^{\star *}$ & & \\
\hline Distort 3 & & & 0.0002 & \\
\hline Distort 4 & & & & 0.007 \\
\hline$S O E$ & $-0.024^{* * *}$ & $-0.024^{* * *}$ & $-0.013^{* * *}$ & -0.014 \\
\hline$F C F$ & $0.260^{* * *}$ & $0.255^{\star * *}$ & $0.248^{\star * *}$ & $0.267^{\star \star \star}$ \\
\hline Distort $1 S O E$ & $0.015^{\star}$ & & & \\
\hline Distort $1 S O E F C F$ & -0.058 & & & \\
\hline Distort $2 S O E$ & & $0.012^{*}$ & & \\
\hline Distort $2 S O E F C F$ & & -0.040 & & \\
\hline Distort $3 S O E$ & & & 0.0002 & \\
\hline Distort $3 S O E F C F$ & & & -0.005 & \\
\hline Distort $4 S O E$ & & & & 0.007 \\
\hline Distort $4 S O E F C F$ & & & & $-0.115^{\star}$ \\
\hline cash & $-0.075^{\star * *}$ & $-0.076^{* * *}$ & $-0.079^{* * *}$ & $-0.075^{\star * *}$ \\
\hline$R O A$ & $0.057^{*}$ & $0.057^{\star}$ & $0.060^{* *}$ & $0.056^{*}$ \\
\hline growth & $0.027^{\star \star *}$ & $0.027^{\star * *}$ & $0.027^{\star \star *}$ & $0.027^{\star * *}$ \\
\hline ret & $0.008^{\star *}$ & $0.008^{* *}$ & $0.008^{\star *}$ & $0.008^{*}$ \\
\hline top 1 & $0.060^{\star * *}$ & $0.061^{\star * \star}$ & $0.060^{\star * *}$ & $0.059^{\star * *}$ \\
\hline top9_1 & $0.013^{* * *}$ & $0.013^{* * *}$ & $0.013^{* * *}$ & $0.013^{* * *}$ \\
\hline tpay & $-0.003^{\star \star}$ & $-0.003^{\star \star}$ & $-0.003^{\star *}$ & $-0.003^{\star *}$ \\
\hline cons & $0.067^{\star * *}$ & $0.070^{\star * *}$ & $0.063^{\star *}$ & $0.058^{\star *}$ \\
\hline industry & & & & \\
\hline Year & & & & \\
\hline$N$ & 2327 & 2327 & 2319 & 2327 \\
\hline R-squared & 0.1435 & 0.1442 & 0.1457 & 0.1437 \\
\hline Adj R-squared & 0.1305 & 0.1311 & 0.1326 & 0.1306 \\
\hline $\mathrm{F}$ & 10.97 & 12.03 & 11.13 & 10.99 \\
\hline
\end{tabular}

Note: ${ }^{* *},{ }^{* *}$, and ${ }^{*}$ represent the significance levels of $1 \%, 5 \%$, and $10 \%$, respectively.

Table 7. Regression results of underinvestment \& internal cash flow gap group.

\begin{tabular}{ccccc}
\hline & \multicolumn{4}{c}{ Under-inV } \\
\cline { 2 - 5 } Variable & Model (1) & Model (2) & Model (3) & Model (4) \\
\cline { 2 - 5 } & coefficient & coefficient & coefficient & coefficient \\
\hline Distort 1 & -0.001 & & & \\
Distort 2 & & -0.00081 & \\
Distort 3 & & & $0.0003^{* * *}$ & \\
\hline
\end{tabular}




\section{Continued}

\begin{tabular}{|c|c|c|c|c|}
\hline Distort 4 & & & & $0.005^{*}$ \\
\hline$S O E$ & $-0.008^{\star * *}$ & $-0.009^{\star * *}$ & $-0.005^{* * *}$ & -0.001 \\
\hline$S C F$ & $0.130^{\star * *}$ & $0.131^{* * *}$ & $0.132^{* * *}$ & $0.130^{\star * *}$ \\
\hline Distort $1 S O E$ & 0.002 & & & \\
\hline Distort $1 S O E S C F$ & 0.010 & & & \\
\hline Distort $2 S O E$ & & 0.003 & & \\
\hline Distort $2 S O E S C F$ & & 0.007 & & \\
\hline Distort $3 S O E$ & & & $-0.0004^{\star}$ & \\
\hline Distort $3 S O E S C F$ & & & 0.0007 & \\
\hline Distort $4 S O E$ & & & & $-0.010^{* *}$ \\
\hline Distort $4 S O E S C F$ & & & & 0.019 \\
\hline cash & $0.027^{\star * *}$ & $0.027^{\star * *}$ & $0.027^{\star * *}$ & $0.028^{\star * *}$ \\
\hline$R O A$ & $0.03^{* * *}$ & $0.036^{* * *}$ & $0.037^{* * *}$ & $0.0356^{* * *}$ \\
\hline growth & -0.001 & -0.001 & -0.001 & -0.001 \\
\hline ret & -0.001 & 0.000 & -0.001 & -0.001 \\
\hline top 1 & 0.003 & 0.003 & 0.003 & 0.003 \\
\hline top9_1 & 0.001 & 0.001 & 0.001 & 0.001 \\
\hline tpay & $-0.002^{\star * *}$ & $-0.002^{\star * *}$ & $-0.002^{* * *}$ & $-0.002^{* * *}$ \\
\hline cons & $0.063^{* * *}$ & $0.063^{\star * *}$ & $0.059^{\star * *}$ & $0.059^{* * *}$ \\
\hline industry & \multicolumn{4}{|c|}{ Control } \\
\hline Year & \multicolumn{4}{|c|}{ Control } \\
\hline$N$ & 5301 & 5301 & 5284 & 5296 \\
\hline R-squared & 0.115 & 0.1153 & 0.115 & 0.1151 \\
\hline AdjR-squared & 0.1093 & 0.1095 & 0.1093 & 0.1094 \\
\hline F & 20.12 & 20.18 & 20.06 & 20.13 \\
\hline
\end{tabular}

Note: ${ }^{* *},{ }^{* *}$, and ${ }^{*}$ represent the significance levels of $1 \%, 5 \%$, and $10 \%$, respectively.

incentive could relatively relieve entrustment agency problems in an effective way.

\section{Conclusions}

Taking listed A share company data in $2008-2015$ as the sample, the thesis studies the different influences of credit allocation distortion on the investment efficiency of state-owned companies and non state-owned companies through constructing interprovincial credit distortion indicator.

Firstly, listed companies have more serious underinvestment degree than overinvestment, which proves that financing constraint is a major constraint for corporate development. Secondly, comparing with state-owned companies, non state-owned companies encounter more underinvestment and overinvestment 
problems. The underinvestment action in non state-owned companies is primarily subject to financing constraints. While non state-owned companies with free cash flow affluence usually have strong financing ability but suffer from few financial constraints. It might be reflected by the radical inclination, or the inclination of constructing imperial empire, of managers in entrustment agency problems. Thirdly, although credit allocation distortion does not have significant direct influences on overinvestment, it could apparently aggravate the overinvestment degree in provincial state-owned companies. Furthermore, when regional credit resources are more allocated to state-owned companies, the underinvestment degree of regional listed companies will be aggravated to some degree. This is in particular true to non state-owned companies. It implies that credit resource allocation imbalance will weaken corporate investment efficiency. Finally, executive remuneration incentive could obviously relieve corporate entrustment agency problems and accordingly prohibit corporate investment inefficiency actions.

On account of above research conclusions, the thesis holds that positive promotion of reformation in state-owned companies and establishment of sound modern corporate management system will help improve state-owned companies' competiveness and raise fund utilization efficiency. While promoting financial market reformation, it is essential to build up a multi-layer financial system including PE and VC and add the proportion of direct financing. This is an important move to enhance the economic capabilities of financial services entities. In the aspect of credit market information flow, companies could get rid of financing dilemma by developing the power of financing technology, improving credit approval ability and efficiency, reducing information asymmetry. Finally, rational introduction of equity incentive, employee shareholding plan and other executive incentive measures to corporate governance will contribute to increasing corporate values.

\section{References}

[1] Myers, S.C. and Majluf, N.S. (1984) Corporate Financing and Investment Decisions When Firms Have Information that Investors Do Not Have. Journal of Financial Economics, 13, 187-221. https://doi.org/10.1016/0304-405X(84)90023-0

[2] Fazzari, S.M., Hubbard, R.G. and Petersen, B.C. (1988) Financing Constraints and Corporate Investment. Brookings papers on Economic Activity, 1, 141-195. https://doi.org/10.2307/2534426

[3] Jensen, M.C. and Meckling, W.H. (1976) Theory of the Firm: Managerial Behavior, Agency Costs and Ownership Structure. Journal of Financial Economics, 3, 303-360. https://doi.org/10.1016/0304-405X(76)90025-8

[4] Shleifer, A. and Vishny, R.W. (1989) Management Entrenchment: The Case of Manager-Specific Investments. Journal of Financial Economics, 25, 123-129. https://doi.org/10.1016/0304-405X(89)90099-8

[5] Jensen, M.C. (1986) Agency Costs of Free Cash Flow, Corporate Finance, and Takeovers. American Economic Review, 76, 323-329. 
[6] Li, S.H., Zou, P. and Song, X.Z. (2015) Monetary Policy, Allocation of Credit Resources and Financial Leakage-Empirical Evidence from Chinese Listed Companies. Economic Science, 3, 77-85.

[7] Xin, Q.Q., Lin, B. and Wang, Y.C. (2007) Government Control, Executive Remuneration and Capital Investment. Economic Studies, 8, 110-122.

[8] Zhang, H.H. and Wang, Z.J. (2010) Government Intervention, Government Objectives and Over-Investment in State-Owned Listed Companies. Corporate Governance, 13, 101-108.

[9] Jiang, L., Cao, Y.Q. and Liao, D.S. (2015) Study on the Relationship between Governance Structure and Investment Efficiency-Based on the Analysis of State-Owned and Private Listed Companies. Financial Issues Study, 10, 104-110.

[10] Zhang, S. (2014) Research on Credit Financing Difference and Investment Moderation Based on the Relationship between Enterprises and Enterprises. Ph.D. Thesis, South China University of Technology, Guangzhou.

[11] Richardson, S. (2006) Over-Investment of Free Cash Flow. Review of Accounting Studies, 11, 159-189.

[12] Liu, R.M. (2011) Financial Repression, Ownership Discrimination and Growth Drag-A Review of the Efficiency Losses of State-Owned Enterprises. Economics, 2, 603-617.

[13] Zou, P.F., Liu, J. and Xie, F.M. (2016) The Mechanism of Credit Resource Allocation Affecting Economic Growth-An Empirical Study Based on 2006-2014 Dynamic Panel Data. Financial Forum, 8, 33-41. 